\title{
NUCLEATION AND GROWTH OF EUTECTIC CARBIDES IN AISI D2 TOOL STEEL MODIFIED BY RARE EARTH ELEMENTS: EXPERIMENTAL AND MODELLING APPROACHES
}

\author{
NUKLEACIJA IN RAST EVTEKTIČNIH KARBIDOV V ORODNEM \\ JEKLU TIPA AISI D2, MODIFICIRANEM Z ELEMENTI REDKIH \\ ZEMELJ: EKSPERIMENTALNI IN MODELSKI PRISTOPI
}

\author{
Klemen Zelič1, Matjaž Godec ${ }^{2}$ \\ ${ }^{1}$ University of Ljubljana, Faculty of Mechanical Engineering, Laboratory for Internal Combustion Engines and Electromobility, Aškerčeva 4, \\ 1000 Ljubljana, Slovenia \\ ${ }^{2}$ Institute of Metals and Technology, Physics and Chemistry of Materials Department, Lepi pot 11, 1000 Ljubljana, Slovenia \\ klemen.zelic@fs.uni-lj.si
}

Prejem rokopisa - received: 2018-02-15; sprejem za objavo - accepted for publication: 2018-09-10

doi:10.17222/mit.2018.024

\begin{abstract}
AISI D2 tool steel from the group of cold work tool steels was modified by rare earth elements (REEs). Small additions of the REEs to the steel melt led to the changed chromium eutectic carbides morphology in the steel as-cast microstructure. REEs impact on nucleation and growth of eutectic carbides in AISI D2 tool steel was investigated by simulation. In order to simulate eutectic reaction phase, field model was build. Dynamic partial differential equation system of the phase field model was solved by finite volumes method. Parameters of the model were determined by comparison between non-modified and rare earth (RE) modified AISI D2 tool steel samples, characterized by scanning electron microscopy (SEM) imaging, energy dispersive X-ray spectroscopy (EDS) and classical chemical analysis. Beside general morphological change of eutectic carbides from lamellar to globular due to RE modification, our model is capable of explaining small eutectic carbide morphological features. From the results nucleation and growth mechanisms of eutectic phase in RE modified AISI D2 steel can be concluded.

Keywords: AISI D2 tool steel, nucleation, phase field modeling
\end{abstract}

Jeklo tipa AISI D2 iz skupine orodnih jekel za delo v hladnem smo modificirali z elementi redkih zemelj. Majhni dodatki elementov redkih zemelj v talino so povzročili spremembo morfologije evtektičnih kromovih karbidov v liti mikrostrukturi jekla. Za preučevanje vpliva redkih zemelj na nukleacijo in rast evtektičnih karbidov v jeklu AISI D2 smo izdelali simulacijo evtektične reakcije. Za izdelavo simulacije smo uporabili modelski pristop faznega polja. Sistem dinamičnih parcialnih diferencialnih enačb modela smo rešili z metodo končnih volumnov. Parametre modela smo določili s primerjavo vzorcev jekla $\mathrm{z}$ dodatkom redkih zemelj in brez. Za karakterizacijo so bile uporabljene tehnike slikanja z vrstičnim elektronskim mikroskopom (SEM), disperzivna energijska spektroskopija X-žarkov (EDS) ter klasična kemijska analiza. Poleg splošne spremembe morfologije evtektičnih karbidov zaradi modifikacije iz lamelarne v globularno je predstavljeni model sposoben tudi opisa lokalnih posebnosti morfologije evtektičnih karbidov v modificiranem jeklu. S pomočjo rezultatov modela lahko dobro razložimo mehanizme nukleacije in rasti evtektičnih karbidov v jeklu tipa ASIS D2, modificiranem z elementi redkih zemelj.

Ključne besede: AISI D2 orodno jeklo, nukleacija, modeliranje faznega polja

\section{INTRODUCTION}

AISI D2 steel from the group of cold-work tool steels is used when wear resistance is important, such as blanking, forming dies and thread-rolling dies, cutting tools, stamping, woodworking and molding tools for plastics. ${ }^{1}$ Due to the high carbon and chromium contents, large eutectic chromium carbides form during the solidification. Carbides in the as-cast microstructure are undesirable because they are points where cracks initiate during the steel's post processing (usually forging). Thus, it is important to investigate ways in which we can control the process of casting and solidification, for example, by using small amounts of modifying agents (different chemical elements) that are added to the molten steel in order to influence the microstructure during solidification. ${ }^{2}$
In later years, modification of melt by rare earth elements (REEs) prior to casting showed good potential for influencing morphology of eutectic carbides in as-cast microstructure of high - chromium high - carbon tool steels. Investigations show that shape, size, morphology and type of eutectic carbide can be modified by rare earth (RE) additions..$^{3-10}$

Even though a lot of successful experimental executions of eutectic carbide modification in high - chromium high - carbon tool steels by REEs exist in literature, ${ }^{3-13}$ governing mechanisms of eutectic carbide modification are not well understood. There are four different possible explanation proposed in literature. Li et al. ${ }^{8}$ proposed the first explanation that was later also used by Fu and Xing ${ }^{5}$ and $\mathrm{Qu}$ et al. ${ }^{6}$ According to this explanation, segregations of REEs to the melt during solidification enrich the melt at the tips of the growing dendrites. This brings high compositional undercooling, 


\section{K. ZELIČ, M. GODEC: NUCLEATION AND GROWTH OF EUTECTIC CARBIDES IN AISI D2 TOOL STEEL ...}

which promotes the branching of dendrites and consequently refined eutectic carbides in interdendritic regions. Second possible explanation of the eutectic carbide modification by REEs was also proposed by $\mathrm{Li}$ et al. ${ }^{8}$ It states that segregations of REEs to the melt during solidification result in the reduced carbon activity in the remaining melt. This further leads to the initiation of eutectic reaction at higher solid (austenite) ratios. Dendrite arm spacing is reduced this way and eutectic carbides solidified in interdentdritic spaces are refined. Third possible explanation that is also capable of explaining change in carbide type due to RE modification states that modification of non-metallic inclusions by REEs in the melt is responsible for the carbide change. ${ }^{4,7}$ According to this theory RE modified non-metallic inclusions act as efficient heterogeneous nuclei for the eutectic carbides. Consequently, morphology, size and type of eutectic carbides is changed in comparison to non-modified steel. In our previous work ${ }^{11-13}$ we proposed new possible mechanism that explains change in morphology of eutectic carbides in AISI D2 tool steel. The change in morphology of eutectic carbides is the result of oxygen and sulfur depletion in the melt, due to REEs high affinity to those two elements. Their theory is firmly supported also by modelling of eutectic reaction and not only experimental observation.

Investigation presented in this paper shows important contribution to the clarification of which of four possible explanations is more likely to be true. It is focused only on nucleation of eutectic reaction by $\mathrm{RE}$ modified non-metallic inclusions and their effect on growth of eutectic carbides. Investigation was conducted in two phases. First phase includes successful experimental execution of AISI D2 tool steel modification and the second phase is committed to phase field modeling of eutectic reaction, ${ }^{14-18}$ that provides good insight in the governing mechanisms.

The original contribution of this paper arises from the fact that independency of eutectic carbide morphology in cold work tool steel on non-metallic inclusion type was proved beyond doubt for the first time. With the connection between experimental and modeling observations it was proved that RE modified non-metallic inclusions in AISI D2 tool steel modified by REEs are not the reason for the change in morphology of $\mathrm{Cr}_{7} \mathrm{C}_{3}$ eutectic carbides.

\section{EXPERIMENTAL PART}

\subsection{Sample Preparation}

AISI D2 tool steel was melted in open induction furnace. It was cast in five cylindrical metallic molds to obtain five $4 \mathrm{~kg}$ ingots with $8 \mathrm{~cm}$ diameter and height of approximately $10 \mathrm{~cm}$. Small additions of rare earth elements (REEs) in the form of Ce mischmetal (Table 1) were introduced in the melt prior to last three ingots casting. All ingots were cast under the same conditions. This way comparable ingots of non-modified and RE modified AISI D2 tool steel were obtained. Samples were cut out of ingots by water jet slicer. Since microstructural differences between samples from all ingots were independent of the spatial position of sample in ingot, only samples from geometrical center of ingots are presented in this paper. Result section of this paper includes only the comparison between samples form first and fifth casted ingot, since differences between this two samples are the most significant. Samples were further prepared for microscopy by grinding, polishing and etching.

Table 1: Chemical composition of Ce mischmetal

\begin{tabular}{|c|c|c|c|c|}
\hline Element & $\mathrm{Ce}$ & $\mathrm{La}$ & $\mathrm{Nd}$ & $\mathrm{Pr}$ \\
\hline$w / \%$ & $45-55$ & $20-35$ & $12-20$ & $5-8$ \\
\hline
\end{tabular}

\subsection{Characterization}

All characterization was done on the as-cast condition of the AISI D2 tool steel. The chemical composition of the samples was determined by wet chemical analysis (Table 2). Content of silicon was determined gravimetrically, content of carbon was analyzed with ELTRA CS-800, and all other elements were analyzed with optical emission spectrometry with inductively coupled plasma (ICP-OES) on Aglient 720. The results of the analysis are presented in Table 2, where the chemical compositions of both ingots are shown. Microstructure investigations were performed with a Jeol JSM - 6500F field emission scanning electron microscope (SEM) with secondary and backscattered electron detectors. Type of non-metallic inclusions in the samples was determined by energy-dispersive X-ray spectroscopy (EDS) on SEM. Positions and distribution of RE containing non-metallic inclusions were investigated by backscattered electron imaging (BEI) on SEM. Type of inclusions in both samples were determined by electron backscattered diffraction (EBSD) technique on SEM. EBSD measurements showed that type of eutectic carbides in both samples is $\mathrm{Cr}_{7} \mathrm{C}_{3}$. The microstructure consists of martensite and carbides.

Table 2: Chemical composition of non-modified and RE modified AISI D2 tool steel

\begin{tabular}{|c|c|c|c|c|c|c|c|c|c|c|c|c|c|}
\hline Element & $\mathrm{C}$ & $\mathrm{Si}$ & $\mathrm{Mn}$ & $\mathrm{Cr}$ & $\mathrm{Cu}$ & $\mathrm{Ni}$ & Mo & V & $\mathrm{Ce}$ & $\mathrm{La}$ & $\mathrm{Nd}$ & $\mathrm{Pr}$ & $\mathrm{Fe}$ \\
\hline Non-mod. & 1.42 & 0.23 & 0.21 & 10.1 & 0.08 & 0.17 & 0.60 & 0.75 & 1 & I & 1 & 1 & Bal \\
\hline RE mod. & 1.41 & 0.22 & 0.21 & 10.3 & 0.08 & 0.17 & 0.59 & 0.80 & 0.013 & 0.008 & 0.005 & 1 & Bal \\
\hline
\end{tabular}




\section{MODELLING}

Nucleation and growth of eutectic carbides in AISI D2 tool steel was modelled by phase field approach. ${ }^{19}$ Since three phases are present in the system at the temperature of eutectic reaction (liquid, austenite and $\mathrm{Cr}_{7} \mathrm{C}_{3}$ carbide), two order parameters of phase field are needed for the description of eutectic reaction. Free energy density was minimized for obtaining dynamic equations by Lagrange formalism. ${ }^{20}$ Obtained system of partial differential equations was discretized on two dimensional domain (50 x 50 control volumes) by finite volume method. Discretized dynamic equations of the system were solved by Newton-Raphson method as described in Numerical recipes in C. ${ }^{21}$ Results of simulations were presented as two dimensional plots of the phase field time evolution. Detailed description of used phase field model can be found is described in our previous papers. ${ }^{11,13}$

\subsection{Nucleation}

In order to model heterogeneous nucleation of the eutectic carbides in AISI D2 tool steel, non-metallic inclusions were introduced to the model. During simulation of melt cooling such non-metallic inclusions act as heterogeneous nuclei either for eutectic carbides or austenitic phase. Non-metallic inclusions were introduced to the model as the fourth existing phase in the system that is not affected by temperature but participate in the reaction only by surface interactions with other three phases (liquid, austenite and $\mathrm{Cr}_{7} \mathrm{C}_{3}$ carbide). The introduction of additional surface to the system necessarily calls for two additional boundary conditions. First boundary condition that was used on the surface of nonmetallic inclusion prohibits any flux of carbon from melt to the bulk of inclusion. This boundary condition was implemented by setting chemical potential gradient at the surface of non-metallic inclusion to zero. Second boundary condition on the surface of non-metallic inclusion was much less trivial. Natural boundary condition was used,,$^{20,22}$ that describe the connection between non dimensional molarity of carbon and surface free energy between inclusion and melt:

$$
\hat{n} \kappa \nabla c=\frac{\partial \gamma}{\partial c}
$$

$\hat{n}$ is the unit vector normal to the surface of the inclusion, $\nabla$ is gradient operator, $c$ is non dimensional molarity of carbon, $\kappa$ is gradient penalty coefficient and $\gamma$ denotes surface free energy of interphase between non-metallic inclusion and surrounding phase. Function $\gamma(\mathrm{c})$ is the one determining the type of non-metallic inclusion. Linear interpolation was used for the evaluation of function $\gamma(\mathrm{c})$ between two boundary values of surface free energy of austenite/inclusion and carbide/ inclusion interfaces. Positive slope of $\gamma(\mathrm{c})$ in the model leads to the carbon enrichment of the melt in the close surroundings of non-metallic inclusion and consequentially nucleation of carbide. Negative slope of $\gamma(\mathrm{c})$ results in the depletion of carbon in the non-metallic inclusion surroundings and consequently austenite is nucleated. The boundary values and consequently the slope of $\gamma(\mathrm{c})$ surface free energy depends on the crystallographic misfit between crystal lattices of two phases forming the interface. According to the misfit of crystal lattice we divided inclusions in two groups. The first one that show lower crystallographic misfit when forming interface with austenite in comparison to $\mathrm{Cr}_{7} \mathrm{C}_{3}$ carbide $(\partial \gamma / \partial c<0)$ and second type opposite $(\partial \gamma / \partial c>0)$. Nonmetallic inclusions of the first type are better heterogeneous nuclei for the austenite phase and second type non-metallic inclusions nucleate $\mathrm{Cr}_{7} \mathrm{C}_{3}$ carbide more efficiently than austenite. This way simulations enabled good insight in the nucleation process of eutectic reaction on different types of non-metallic inclusions that were present in the melt.

\section{RESULTS AND DISCUSSION}

Investigation of effect of non-metallic inclusions was done by comparison between experimental and modeling results. Figure 1 shows comparison between SEM BEI
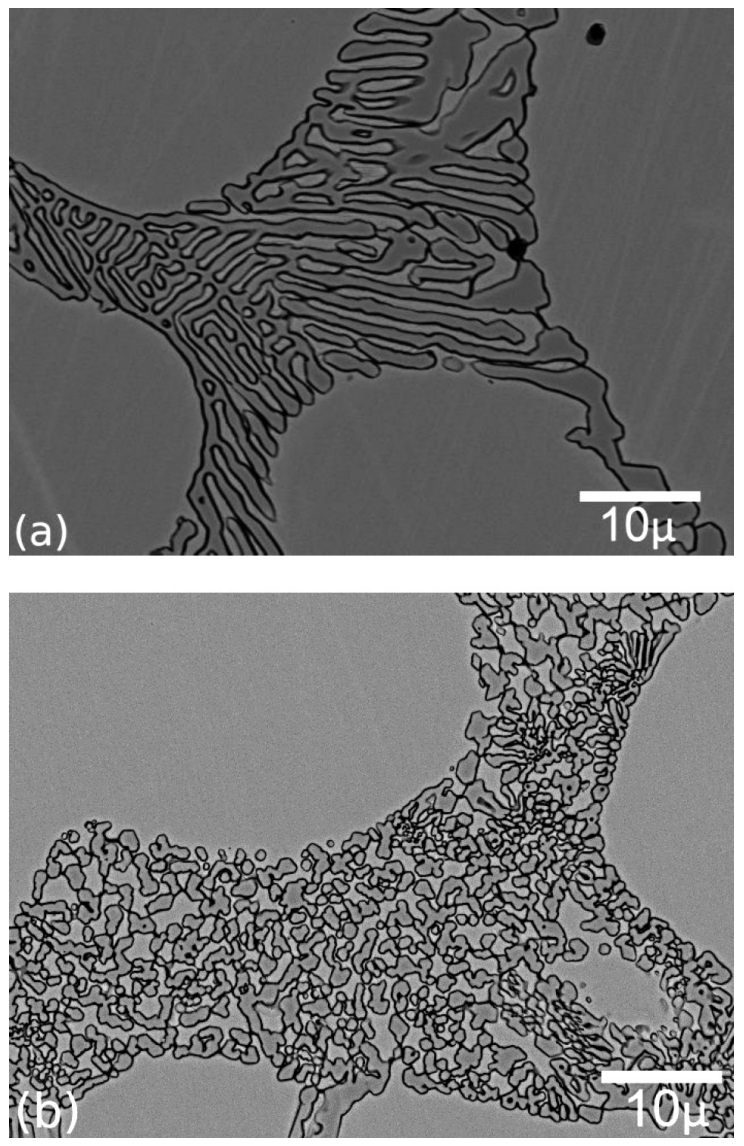

Figure 1: SEM BEI of $\mathrm{Cr}_{7} \mathrm{C}_{3}$ eutectic carbide in: a) non-modified as-cast AISI D2 tool steel and b) RE modified as-cast AISI D2 tool steel 
micrographs of non-modified and RE modified AISI D2 tool steel. ${ }^{11,13}$

From Figure 1 it can be seen that RE modification affects the morphology of eutectic carbides in AISI D2 tool steel as-cast microstructure. Whether or not the REEs containing non-metallic inclusions are responsible for such morphological differences was tested in few different ways. Positions of REEs containing non-metallic inclusions were measured first. Since REEs have by far largest atomic weight among all elements present in the samples they appear bright on the SEM BEI micrographs. The first proof that REEs containing non-metallic inclusion does not influence the morphology of eutectic carbides arises from the fact that no such inclusions were found inside the eutectic region in as-cast microstructure of RE modified AISI D2 tool steel even after investigation of large number of samples. Figure 2 show two SEM BEI micrographs that show typical positioning of REEs containing non-metallic inclusions in RE modified samples (bright spots in images). They are always found inside the matrix of steel.

Type of non-metallic inclusions in samples were determined by EDS measurements on SEM. The EDS spectra and detailed discussion of the EDS results can be found in our previous work. ${ }^{12}$ Beside $\mathrm{Al}_{2} \mathrm{O}_{3}$ an $\mathrm{MnS}$ non-metallic inclusions that were found in non-modified
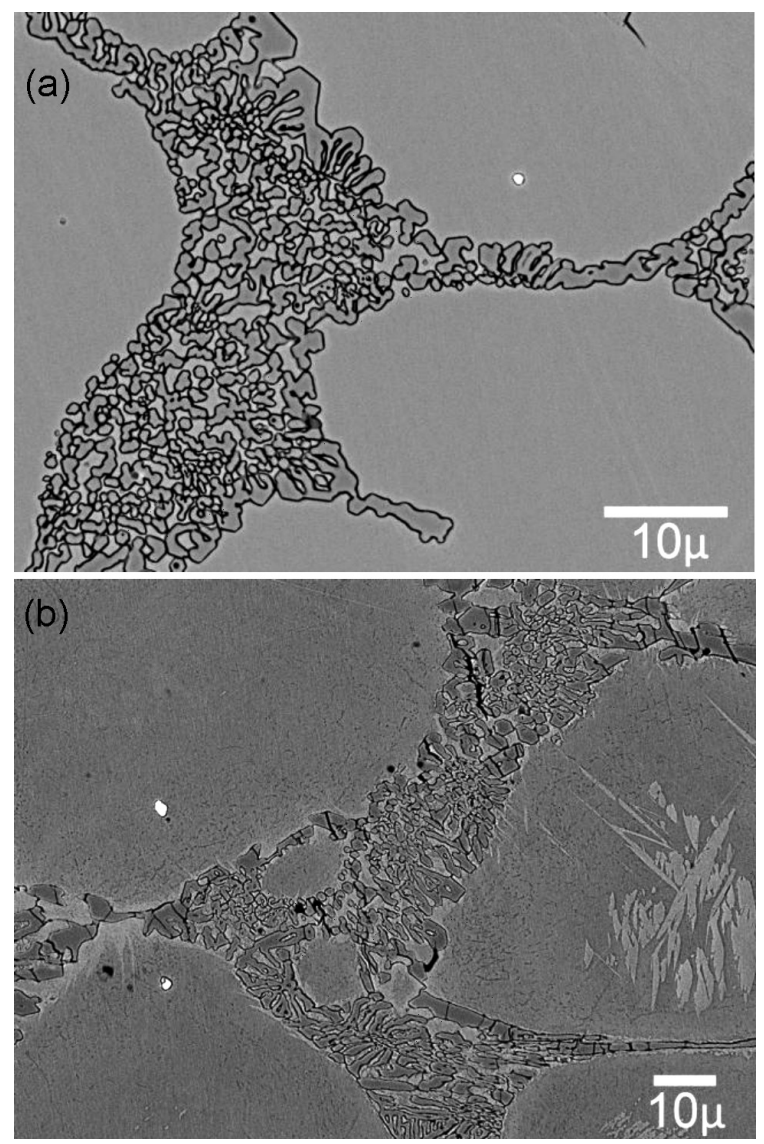

Figure 2: Position of $\mathrm{RE}_{2} \mathrm{O}_{2} \mathrm{~S}$ non-metallic inclusions in $\mathrm{RE}$ modified AISI D2 tool steel as-cast microstructure samples, complex oxy-sulfide $\mathrm{RE}_{2} \mathrm{O}_{2} \mathrm{~S}$ inclusions were found in RE modified samples (bright spots in Figure 2). Such inclusions were expected due to the high affinity of REEs to oxygen and sulfur. The only difference regarding non-metallic inclusion between non-modified and RE modified samples therefore is appearance of $\mathrm{RE}_{2} \mathrm{O}_{2} \mathrm{~S}$ in RE modified samples. This finding is in good agreement with Hamidzadeh et al. ${ }^{7}$

Second factor supporting the theory that REEs containing non-metallic inclusions do not influence final morphology of eutectic carbide in RE modified AISI D2 tool steel arises from the simulations presented in Figure 3. Figure 3 show two cases. Nucleation of eutectic reaction in CASE 1 occurred on non-metallic inclusion which crystal lattice shows lowest misfit with $\mathrm{Cr}_{7} \mathrm{C}_{3}$ eutectic carbide crystal lattice in comparison to austenite crystal lattice (type 2 inclusion). Simulation of solidification in CASE 2 was nucleated on non-metallic inclusion that shows lowest misfit of crystal lattice with the austenite in comparison to carbide (type 1 inclusion). Even though simulations of solidification in both cases were nucleated by different crystallographic types of non-metallic inclusions, both simulations ended in the

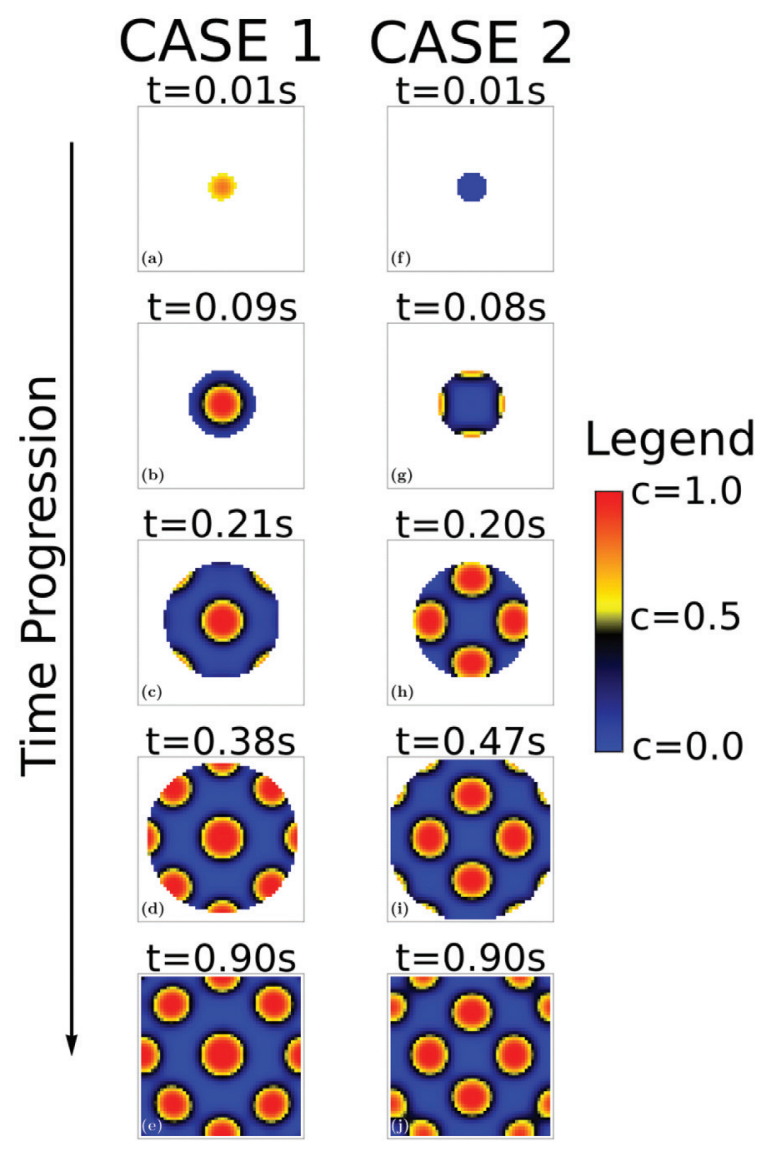

Figure 3: Simulation of nucleation and growth of eutectic carbides in RE modified AISI D2 tool steel. CASE 1 (Figures 3a to 3e) show growth of carbides nucleated on non-metallic inclusion of second type. CASE 2 (Figures $\mathbf{3 f}$ to $\mathbf{3 j}$ ) show growth of carbides nucleated on non-metallic inclusion of first type. White color represents liquid phase (melt), blue color austenite and red color $\mathrm{Cr}_{7} \mathrm{C}_{3}$ carbide. 

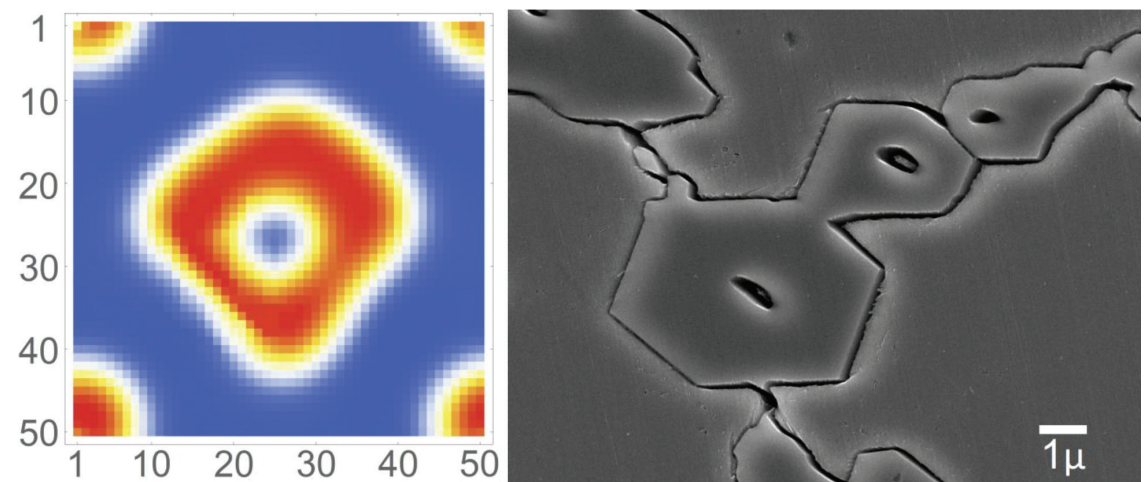

Figure 4: Comparison between simulation and SEM secondary electron image (SEI) of RE modified AISI D2 tool steel as-cast microstructure

same morphologic type of eutectic carbide - globular eutectic. This shows that final morphology of eutectic carbide is independent of the type of nucleation sites.

Independency of final microstructure on type of nucleation sites can also be seen from Figure 4. Simulation presented in Figure 4a was started by nucleation on non-metallic inclusion of the second type (effective austenite nucleation site). Figure 4a shows that nucleation on the non-metallic inclusion that effectively nucleate only austenite phase, resulted in the growth of carbide globule. Globule has a shape of toroid since the first phase that grows in the center of globule is austenite. Carbon enrichment of the melt in the close surrounding leads to the carbide growth around the small austenite core. Very similar morphological features were found in experiment on SEM SEI (Figure 4b). The fact that simulation show carbide globule growth from austenite nucleation site additionally proves that final morphology of eutectic carbides is independent of nucleation sites type. Carbide morphological features found in SEM BEI, presented in Figure 4b, support conclusions made on the basis of simulation well since they provide additional validation of our model.

\section{CONCLUSIONS}

With the connection between modeling and experimental approaches to the RE modification of AISI D2 tool steel investigation, effects of different types of non-metallic inclusion on nucleation and growth of $\mathrm{Cr}_{7} \mathrm{C}_{3}$ eutectic carbides during solidification were studied. It was showed that RE containing non-metallic inclusions in RE modified AISI D2 tool steel do not influence the final morphology of eutectic carbides in the as-cast microstructure. The final morphology of eutectic carbides turned out to be independent of the type of nuclei, that initiated eutectic reaction.

\section{Acknowledgment}

The authors acknowledge the financial support from Slovenian Research Agency (ARRS) (research core funding no. P2-0132). K. Z. acknowledges the ARRS for the provision of Young Research funding for his $\mathrm{PhD}$.

\section{REFERENCES}

${ }^{1}$ A. C. Reardon, Metallurgy for the non-metallurgist, ASM International, 2011

${ }^{2}$ G. Krauss, Steels: processing, structure, and performance. ASM International, 2015

${ }^{3}$ J. Yang, D.-n. Zou, X.-m. Li, Z.-Z. Du, Effect of rare earth on microstructures and properties of high speed steel with high carbon content, Journal of Iron and Steel Research, International, 14 (2007) 1, 47-59, doi: 10.1016/S1006-706X(07)60011-9

${ }^{4}$ X. Zhou, X. Yin, F. Fang, J. Jiang, W. Zhu, Influence of rare earths on eutectic carbides in AISI M2 high speed steel, Journal of Rare Earths, 30 (2012) 10, 1075-1078, doi:10.1016/S1002-0721(12) 60181-1

${ }^{5}$ H. Fu, J. Xing, A study of modification of M2 cast high speed steel, Materialwissenschaft und Werkstofftechnik, 35 (2004) 9, 578-581

${ }^{6}$ M. Qu, Z. Wang, H. Li, Z. Lv, S. Sun, W. Fu, Effects of mischmetal addition on phase transformation and as-cast microstructure characteristics of $\mathrm{m} 2$ high-speed steel, Journal of Rare Earths, 31 (2013) 6, 628-633, doi:10.1016/S1002-0721(12)60332-9

${ }^{7}$ M. A. Hamidzadeh, M. Meratian, A. Saatchi, Effect of cerium and lanthanum on the microstructure and mechanical properties of AISI D2 tool steel, Materials Science and Engineering: A, 571 (2013) Supplement C, 193-198, doi:10.1016/j.msea.2013.01.074

${ }^{8}$ Y. Li, Q.-C. Jiang, Y. Zhao, Z. He, X.-Y. Zhong, Influence of cerium on solidification microstructure of M2 high speed steel, 18 (2000), 134-135

${ }^{9}$ M. Wang, S. Mu, F. Sun, Y. Wang, Influence of rare earth elements on microstructure and mechanical properties of cast high-speed steel rolls, Journal of Rare Earths, 25 (2007) 4, 490-494

${ }^{10}$ M. Boccalini, A. Correa, H. Goldenstein, Rare earth metal induced modification of $\gamma-\mathrm{M}_{2} \mathrm{C}, \gamma-\mathrm{M}_{6} \mathrm{C}$ and $\gamma$-MC eutectics in as cast M2 high speed steel, Materials Science and Technology, 15 (1999) 6, 621-626, doi:10.1179/026708399101506355

${ }^{11}$ K. Zelič, J. Burja, J. P. McGuiness, M. Godec, Effect of rare earth elements on the morphology of eutectic carbides in AISI D2 tool steels: experimental and modelling approaches, Scientific reports, 8 (2018) 1, doi:10.1038/s41598-018-27658-w

${ }^{12}$ K. Zelič, M. Godec, A modified mean-linear-intercept method for distinguishing lamellar and globular eutectic carbides in metallographic samples, Mater. Tehnol., 52 (2018) 1, 83-87, doi:10.17222/ mit.2017.173

${ }^{13} \mathrm{~K}$. Zelič, Effect of the rare-earth elements $\mathrm{Ce}$, La, Nd and Pr on the morphology of eutectic carbides in tool steels: experimental and modelling approaches (doctoral dissertation), 2018

${ }^{14}$ M. Ode, T. Suzuki, S. Kim, W. Kim, Phase - field model for solidification of Fe-C alloys, Science and Technology of Advanced 


\section{K. ZELIČ, M. GODEC: NUCLEATION AND GROWTH OF EUTECTIC CARBIDES IN AISI D2 TOOL STEEL ...}

Materials, 1 (2000) 1, 43-49, 2000. doi:10.1016/S1468-6996(99) 00004-2.

${ }^{15}$ X.-1. Dong, H. Xing, K.-r. Weng, H.-1. Zhao, Current development in quantitative phase-field modeling of solidification, Journal of Iron and Steel Research, International, 24 (2017) 9, 865-878, doi:10.1016/S1006-706X(17)30129-2

${ }^{16}$ N. Moelans, B. Blanpain, P. Wollants, An introduction to phase-field modeling of microstructure evolution, Calphad, 32 (2008) 2, 268-294 doi:10.1016/j.calphad.2007.11.003

${ }^{17}$ B. Nestler, A. A. Wheeler, Phase-field modeling of multi-phase solidification, Computer Physics Communications, 147 (2002) 1, 230-233, 2002, Proceedings of the Europhysics Conference on Computational Physics Computational Modeling and Simulation of Complex Systems, doi:10.1016/S0010-4655(02)00252-7
${ }^{18}$ B. Böttger, G. J. Schmitz, B. Santillana, Multi-phase-field modeling of solidification in technical steel grades, Transactions of the Indian Institute of Metals, 65 (2012) 6, 613-615, doi:10.1007/s12666012-0169-y

${ }^{19}$ N. Provatas, K. Elder, Phase-field methods in materials science and engineering, John Wiley and Sons, 2011

${ }^{20} \mathrm{H}$. Sagan, Introduction to the Calculus of Variations. Courier Corporation, 1969

${ }^{21}$ W. H. Press, S. A. Teukolsky, W. T. Vetterling, B. P. Flannery, Numerical recipes in $\mathrm{C}$ : the art of scientific computing, $2^{\text {nd }}$ ed., Cambridge, 2007, 362-369

${ }^{22}$ L. Gránásy, T. Pusztai, D. Saylor, J. A. Warren, Phase field theory of heterogeneous crystal nucleation, Phys. Rev. Lett., 98 (2007) 3, doi:10.1103/PhysRevLett.98.035703 